\title{
Financial Excesses and Executive Compensation Stickiness
}

\author{
Gan Shengdao ${ }^{1, a}$, Liang Yang ${ }^{1, a}$, Huang Jintao ${ }^{2, b}$ \\ ${ }^{1}$ Sichuan University, Business School, Chengdu, P.R.China \\ ${ }^{2}$ University of Chinese Academy of Sciences, School of Cyber Security, Beijing, P.R.China
}

\begin{abstract}
This research selects China A-share listed companies from 2007-2018 as the research sample, and empirically tests the impact of financial excesses and property rights on the executive compensation stickiness. This study finds that financial excesses have a significant regulating effect on executive compensation stickiness, and the degree of stickiness regulation for enterprises with different property rights is quite different. Financial excesses inhibit executive compensation stickiness in local-state-owned enterprises and non-state-owned enterprises, but have a positive effect when it happens in central-state-owned enterprises
\end{abstract}

\section{Introduction}

Jackson et al.(2008) defined "executive compensation stickiness" as the phenomenon that the marginal reduction in the compensation of enterprise's senior managers when the performance decline is less than the marginal increase in the compensation of enterprise's senior managers[1]. After 2012, more than 50\% of Japanese enterprises have no interest-bearing liabilities or their interest-bearing liabilities are lower than their cash holdings and their equivalents. Japanese academic scholars have named this phenomenon as "no actual borrowing". On this basis, Gan Shengdao sums up a new financial concept--financial excesses[2]. In this case, financial leverage is low, and mainly use of equity capital will intensify the supervision of the shareholders. The compensation system is more in line with the requirements of the principal-agent theory, reflecting a stronger performance sensitivity. Are there significant differences between enterprises with different property rights? We empirically test whether different performance indicators affect the degree of executive compensation stickiness, then verify whether financial excesses have an inhibiting effect on executive compensation stickiness.

This article proceeds as follows. Section 2 reviews the relevant literature and develops hypotheses. Section 3 gives data description and research design. Section 4 provides regression analysis and robustness test. Section 5 concludes the article.

\section{LITERATURE REVIEW AND HYPOTHESIS DEVELOPMENT}

Gaver (1998) finds the asymmetry between CEO compensation and performance indicators: CEO compensation does not decrease when the company's performance declined. A similar pattern exists between CEO compensation and non-operating gains and losses [1]. Jackson (2008) defined the executive compensation stickiness as the phenomenon that the marginal increase of executive compensation when performance change is greater than marginal decrease when performance declines.[3] Since then, foreign scholars have confirmed this discovery from many angles.

Fang Junxiong (2009) takes the financial data of China's listed companies from 2001 to 2007 as the sample. The empirical study shows that the executive compensation of Chinese listed companies initially presents a relatively significant performance sensitivity, but the executive compensation also has the characteristic of stickiness [4]. Domestic scholars find that property rights, company scale, equity structure (Fang Junxiong, 2009), compensation committee (Mao Hongtao etc. 2012), equity incentive strength (Zhao Jianmei etc. 2014), financial asset investment(Bu Danlu etc. 2013), political association (Zhang Aimin etc. 2016), and many other factors have impact on executive compensation stickiness[4-8].

Therefore, this paper explores the influencing factors of executive compensation stickiness from the point of capital structure creatively. There are some differences on executive compensation stickiness among enterprises with different property rights. The main purpose of stateowned enterprises is focusing on allocating social resources, therefore they receive more administrative supervision, public supervision and media supervision. On the contrary, non-state-owned enterprises suffers more loose external supervision. Compared with non-stateowned enterprises, executive compensation of stateowned enterprises is less sticky. The above discussions lead to the following hypothesis in alternative form:

aliangyang@stu.scu.edu.cn; bhuangjintao19@mails.ucas.edu.cn 
H1: State-owned enterprises have a lower degree of stickiness in executive compensation than non-stateowned enterprises.

Because of the mainly use of equity capital, financial excesses enterprises have more supervision from shareholders. Therefore, the salary system developed conforms to the requirements of principal-agent theory, which makes the executive compensation more sensitive to performance. The above discussions lead to the following hypothesis in alternative form:

$\mathrm{H} 2$ : Financial excesses have an inhibiting effect on executive compensation stickiness.

State-owned enterprises is not completely seek to maximize performance, while its main goal is to maintain domestic livelihood issues. Therefore, state-owned enterprises with financial excesses need to take more social responsibility. Making profit is their second purpose $[9,10]$. Therefore, financial excesses promotes the executive compensation of the central-controlled enterprises. However, it inhibits the local-controlled enterprises and private enterprises. The above discussions lead to the following hypothesis in alternative form:

H3: Financial excesses promote the executive compensation stickiness in central-state-owned enterprises, but it inhibits the executive compensation stickiness in local-state-owned enterprises and non-stateowned enterprises.

\section{RESEARCH AND DESIGN}

\subsection{Data Sources}

Initially, our sample is drawn from the intersection data from CSMAR for the period 2007-2018. The selection criteria is as follow: (1) All financial enterprises are excluded; (2) ST and *ST companies are excluded; (3) Samples with missing observation values were eliminated; (4) Excluding the observed value of 2007. After applying these selection criteria, we obtain a sample of 15225 firmyears spanning the period 2008-2018.

\subsection{Variable Description}

\subsubsection{Explained variable}

We use natural logarithm of the average compensation of the top three executives(Intoppay1) and natural logarithm of the average compensation of the top three directors(lntoppay2) to represent the executive compensation.

\subsubsection{Explanatory variable}

Financial excesses $($ Finex $)=($ Monetary capital + Trading financial assets - Interest-bearing liabilities)/ Total assets.

\subsubsection{Control variable}

a) Down: Dummy variable that takes the value of 1 if the company' performance is decline, and 0 otherwise.

b) Pre: Roe and Roa measure the company' performance.

c) Soe: Dummy variable that takes the value of 1 if the company is state-controlled, and 0 otherwise.

d) Centra: Dummy variable that takes the value of 1 if the company is central-state-controlled, and 0 otherwise.

e) Lnrevenue: The natural logarithm of annual operating revenue.

f) Lev: The ratio of long-term liabilities to total assets.

g) First: The largest shareholder shareholding ratio.

h) Dual: Dummy variable that takes the value of 1 if the two posts of chairman and general manager are separated, and 0 otherwise.

i) Board: The proportion of independent directors in the total number of directors.

j) Hold: Dummy variable that takes the value of 1 if the senior management holds the company's stock, and 0 otherwise.

\subsection{Equations}

Referring to the research scheme of Fang Junxiong(2009), Xia Xuehua (2014), Liu Zhongyan(2014) and Zhang Aimin(2016), financial excesses is added on the basic model to form the financial affluence function model[8,11,12].

Model 1: basic model

Intoppay $=\beta_{0}+\beta_{1} *$ Pre $+\beta_{2} *$ Down $+\beta_{3} *$ Down $*$ Pre

$$
\begin{aligned}
& +\beta_{4} * \text { lnrevenue }+\beta_{5} * \text { lev }+\beta_{6} * \text { first } \\
& +\beta_{7} * \text { dual }+\beta_{8} * \text { board }+\beta_{9} * \text { hold } \\
& +\beta_{10} * \text { year }+\beta_{11} * \text { industry }+\varepsilon(1)
\end{aligned}
$$

Model 2: financial excesses model Intoppay $=\gamma_{0}+\gamma_{1} *$ Pre $+\gamma_{2} *$ Down $+\gamma_{3} *$ Down $*$ Pre $+\gamma_{4} *$ Finex $+\gamma_{5} *$ Finex $*$ Pre $+\gamma_{6} *$ Finex $*$ Down $*$ Pre

$+\gamma_{7} *$ lnrevenue $+\gamma_{8} *$ lev $+\gamma_{9} *$ first $+\gamma_{10} *$ dual $+\gamma_{11} *$ board $+\gamma_{12} *$ hold $+\gamma_{13} *$ year

$$
+\gamma_{14} * \text { industry }+\varepsilon(2)
$$

Where, $\beta_{1}+\beta_{3}$ measures the sensitivity of executive compensation to the company's performance when the company's performance declines. This paper expects that $\beta_{1}+\beta_{3}<\beta_{1}\left(\beta_{3}<0\right)$. Model 2 is to test whether financial excesses have an inhibitory effect on executive compensation stickiness of listed companies. Financial excesses is added on the model 1. $\gamma_{1} /\left(\gamma_{1}+\gamma_{6}\right)$ is expected to be less than $\beta_{1} /\left(\beta_{1}+\beta_{3}\right)$ in this paper, so as to verify hypothesis 2 .

\subsection{Descriptive Statistics}

Table 1 presents descriptive statistics for the major variables discussed in section 3, along with additional variables that are used as control variables in our multivariate analysis. $26.7 \%$ of the samples shows a 
performance decline when the company's performance was measured by Roe. Measured by Roa, $55.7 \%$ of the samples showed a performance decline. The median value of Finex is -0.031 . Besides, nearly $50 \%$ of the samples have the phenomenon of financial excesses, indicating that the phenomenon of financial excesses is widespread in Chinese A-share market.

\subsection{Correlation Analysis}

Table 2 presents the Pearson and Spearman correlation matrix for all the variables used in our regression analysis. The two measures for executive compensation, Intoppay 1 and lntoppay2, are significantly and positively correlated with each other. Executive compensation variables and company performance variables are at $1 \%$ level of significant positive correlation, which to a certain extent. Listed companies in China have been basically established performance-related compensation mechanism, and the existing research results are basically identical[13-17].

\section{EMPIRICAL TEST AND ANALYSIS}

\subsection{Regression Analysis}

Table 3 shows the regression results of Model 1. When the performance rises, the regression coefficient of executive compensation on ROE is 1.952, which is significantly positive at the $1 \%$ level. When corporate performance declines, the sensitivity coefficient $\beta_{1}+\beta_{3}$ of executive compensation and performance is 0.957 (1.952-0.995). The increase in executive compensation when performance increases is 2.04 times the decrease in executive compensation when performance declines, that is, the stickiness value is $2.04(1.952 / 0.957)$.

Table 1. DESCRIPTIVE STATISTICS

\begin{tabular}{llllllll}
\hline variable & $\mathbf{N}$ & mean & $\mathbf{p 5 0}$ & sd & min & max & range \\
\hline lntoppay1 & 15225.00 & 13.10 & 13.09 & 0.71 & 11.35 & 15.05 & 3.71 \\
lntoppay2 & 15225.00 & 12.96 & 12.97 & 0.77 & 10.94 & 14.99 & 4.05 \\
Roe & 15225.00 & 0.06 & 0.07 & 0.11 & -0.54 & 0.32 & 0.86 \\
Down & 15225.00 & 0.27 & 0 & 0.44 & 0 & 1 & 1 \\
Roa & 15225.00 & 0.04 & 0.03 & 0.05 & -0.15 & 0.22 & 0.37 \\
Droa & 15225.00 & 0.56 & 1 & 0.50 & 0 & 1 & 1 \\
Finex & 15225.00 & -0.02 & -0.03 & 0.23 & -0.54 & 0.60 & 1.14 \\
soe & 15225.00 & 0.41 & 0 & 0.49 & 0 & 1 & 1 \\
centra & 15225.00 & 0.14 & 0 & 0.35 & 0 & 1 & 1 \\
lnrevenue & 15225.00 & 20.11 & 20.36 & 2.08 & 12.91 & 24.54 & 11.62 \\
lev & 15225.00 & 0.06 & 0.01 & 0.09 & 0 & 0.41 & 0.41 \\
first & 15225.00 & 0.35 & 0.34 & 0.15 & 0.09 & 0.75 & 0.66 \\
dual & 15225.00 & 0.77 & 1 & 0.42 & 0 & 1 & 1 \\
board & 15225.00 & 0.37 & 0.33 & 0.05 & 0.33 & 0.57 & 0.24 \\
hold & 15225.00 & 0.69 & 1 & 0.46 & 0 & 1 & 1 \\
\hline
\end{tabular}

The coefficient of the crossover term Down * Roe is significantly negative at the $1 \%$ level ( $\mathrm{t}$ value is -9.10$)$, indicating that the executive compensation stickiness is widespread in China A-share listed companies. The existing research results are basically identical[18-21].
The results show that the stickiness value increases in the order of central-state-owned enterprises, local-stateowned enterprises and non-state-owned enterprises, which are 1.44, 1.98 and 2.66. The reason should be that compared with non-state-owned enterprises, local-stateowned enterprises,

Table 2. PEARSON CORRELATIONS

\begin{tabular}{|c|c|c|c|c|c|c|c|c|}
\hline & Intoppay1 & Intoppay2 & Roe & Down & Roa & Droa & Finex & soe \\
\hline Intoppay1 & 1 & & & & & & & \\
\hline Intoppay2 & $0.859 * * *$ & 1 & & & & & & \\
\hline Roe & $0.244 * * *$ & $0.242 * * *$ & 1 & & & & & \\
\hline Down & $-0.111 * * *$ & $-0.116^{* * *}$ & $-0.284 * * *$ & 1 & & & & \\
\hline Roa & $0.206^{* * *}$ & $0.207 * * *$ & $0.718 * * *$ & $-0.195 * * *$ & 1 & & & \\
\hline Droa & $-0.035 * * *$ & $-0.030 * * *$ & $-0.222 * * *$ & $0.123 * * *$ & $-0.314 * * *$ & 1 & & \\
\hline Finex & 0 & 0.007 & $0.199 * * *$ & $-0.047 * * *$ & $0.341 * * *$ & $-0.025 * * *$ & 1 & \\
\hline soe & $0.044 * * *$ & $-0.095 * * *$ & $-0.056 * * *$ & $0.055^{* * *}$ & $-0.077 * * *$ & $-0.037 * * *$ & $-0.191 * * *$ & 1 \\
\hline centra & $0.101 * * *$ & $-0.043 * * *$ & $-0.030 * * *$ & 0.009 & $-0.053 * * *$ & $-0.017^{* *}$ & $-0.057 * * *$ & $0.493 * * *$ \\
\hline Inrevenue & $0.174 * * *$ & $0.159 * * *$ & $0.099 * * *$ & $-0.088 * * *$ & $0.087 * * *$ & 0 & $-0.061 * * *$ & $0.119 * * *$ \\
\hline lev & $0.135 * * *$ & $0.096^{* * *}$ & $-0.049 * * *$ & 0 & $-0.152 * * *$ & $0.019 * *$ & $-0.562 * * *$ & $0.218 * * *$ \\
\hline first & $0.019 * *$ & $-0.036 * * *$ & $0.105 * * *$ & -0.001 & $0.121 * * *$ & -0.004 & 0.012 & $0.212 * * *$ \\
\hline
\end{tabular}




\begin{tabular}{|c|c|c|c|c|c|c|c|c|}
\hline dual & $-0.023 * * *$ & $-0.024 * * *$ & -0.007 & $0.038 * * *$ & -0.010 & $-0.027 * * *$ & $-0.101 * * *$ & $0.276 * * *$ \\
\hline board & $0.019 * *$ & $-0.033 * * *$ & $-0.027 * * *$ & -0.001 & $-0.036 * * *$ & 0.005 & -0.001 & $-0.046^{* * *}$ \\
\hline \multirow[t]{2}{*}{ hold } & $0.157 * * *$ & $0.197 * * *$ & $0.076 * * *$ & $-0.072 * * *$ & $0.072 * * *$ & $0.022 * * *$ & $0.080 * * *$ & $-0.260 * * *$ \\
\hline & centra & Inrevenue & lev & first & dual & board & hold & \\
\hline centra & 1 & & & & & & & \\
\hline Inrevenue & $0.076 * * *$ & 1 & & & & & & \\
\hline lev & $0.099 * * *$ & $0.096 * * *$ & 1 & & & & & \\
\hline first & $0.123 * * *$ & $0.171 * * *$ & $0.066^{* * *}$ & 1 & & & & \\
\hline dual & $0.163 * * *$ & $0.051 * * *$ & $0.090 * * *$ & $0.047 * * *$ & 1 & & & \\
\hline board & -0.012 & $-0.026 * * *$ & 0.008 & $0.048 * * *$ & $-0.100 * * *$ & 1 & & \\
\hline hold & $-0.125^{* * *}$ & $0.092 * * *$ & $-0.069 * * *$ & $-0.211 * * *$ & $-0.152 * * *$ & $0.018^{* *}$ & 1 & \\
\hline
\end{tabular}

Notes: Pearson correlations (left below) and spearman correlations (right above). *, **, *** significant at $0.10,0.05$ and 0.01 levels.

especially central-state-owned enterprises, face more administrative supervision and public opinion supervision, and have a more complete compensation system, which is conducive to alleviating compensation stickiness.
After adding financial excesses, the regression coefficient of Roe in Table 3 is 2.112. The stickiness value $\gamma_{1} /\left(\gamma_{1}+\gamma_{6}\right)$ is 1.57 , which is significantly lower than the stickiness value 2.04 before adding financial excesses.

Table 3. REGRESSION ANALYSIS

\begin{tabular}{|c|c|c|c|c|c|c|c|c|}
\hline \multicolumn{9}{|l|}{ Intoppay1 } \\
\hline & ALL & CSOE & LSOE & NSOE & ALL & CSOE & LSOE & NSOE \\
\hline \multirow[t]{2}{*}{ lnrevenue } & $0.048 * * *$ & $0.020 * * *$ & $0.034 * * *$ & $0.062 * * *$ & $0.948 * * *$ & $0.874 * * *$ & $0.599 * * *$ & $1.236 * * *$ \\
\hline & $(-16.34)$ & $(-3.16)$ & $(-7.62)$ & $(-13.31)$ & $(-12.46)$ & $(-4.65)$ & $(-5.12)$ & $(-10.63)$ \\
\hline \multirow[t]{2}{*}{ lev } & $0.701 * * *$ & $0.560 * * *$ & $0.219 * *$ & $1.008 * * *$ & -0.039 & $0.179^{*}$ & $-0.167 * *$ & $-0.103^{* *}$ \\
\hline & $(-10.42)$ & $(-3.36)$ & $(-2.20)$ & $(-9.63)$ & $(-1.08)$ & $(-1.92)$ & $(-2.55)$ & $(-2.10)$ \\
\hline \multirow[t]{2}{*}{ first } & -0.012 & $0.214^{* *}$ & $-0.134 * *$ & $-0.085^{*}$ & -0.005 & $-0.183 * * *$ & -0.004 & $-0.049 * * *$ \\
\hline & $(-0.33)$ & $(-2.31)$ & $(-2.02)$ & $(-1.72)$ & $(-0.39)$ & $(-4.34)$ & $(-0.11)$ & $(-3.54)$ \\
\hline \multirow[t]{2}{*}{ dual } & -0.007 & $-0.186^{* * *}$ & -0.007 & $-0.050 * * *$ & 0.025 & 0.175 & 0.173 & -0.056 \\
\hline & $(-0.59)$ & $(-4.36)$ & $(-0.21)$ & $(-3.57)$ & $(-0.27)$ & $(-0.86)$ & $(-0.97)$ & $(-0.45)$ \\
\hline \multirow[t]{2}{*}{ board } & 0.001 & 0.067 & 0.134 & -0.065 & $0.129 * * *$ & $0.216^{* * *}$ & $0.208 * * *$ & $0.073 * * *$ \\
\hline & $(-0.01)$ & $(-0.33)$ & $(-0.74)$ & $(-0.53)$ & $(-11.31)$ & $(-8.60)$ & $(-10.91)$ & $(-4.16)$ \\
\hline \multirow[t]{2}{*}{ hold } & $0.134 * * *$ & $0.214^{* * *}$ & $0.209 * * *$ & $0.079 * * *$ & $2.112 * * *$ & $2.168 * * *$ & $2.302 * * *$ & $2.053 * * *$ \\
\hline & $(-11.66)$ & $(-8.52)$ & $(-10.89)$ & $(-4.50)$ & $(-23.51)$ & $(-9.76)$ & $(-14.74)$ & $(-16.59)$ \\
\hline \multirow[t]{2}{*}{ Pre } & $1.952 * * *$ & $1.727 * * *$ & $2.252 * * *$ & $1.945^{* * *}$ & 0.011 & 0.025 & -0.021 & 0.029 \\
\hline & $(-22.52)$ & $(-9.15)$ & $(-14.60)$ & $(-16.04)$ & $(-0.83)$ & $(-0.75)$ & $(-0.90)$ & $(-1.52)$ \\
\hline \multirow[t]{2}{*}{ Down } & 0.007 & -0.002 & -0.015 & 0.026 & $-0.950 * * *$ & $-0.785^{* *}$ & $-0.923 * * *$ & $-1.133 * * *$ \\
\hline & $(-0.50)$ & $(-0.06)$ & $(-0.63)$ & $(-1.42)$ & $(-7.75)$ & $(-2.50)$ & $(-4.17)$ & $(-7.02)$ \\
\hline \multirow[t]{2}{*}{ Down*Pre } & $-0.995 * * *$ & $-0.530^{* *}$ & $-1.112 * * *$ & $-1.214 * * *$ & $0.948 * * *$ & $0.874 * * *$ & $0.599 * * *$ & $1.236 * * *$ \\
\hline & $(-9.10)$ & $(-2.25)$ & $(-5.79)$ & $(-7.94)$ & $(-12.46)$ & $(-4.65)$ & $(-5.12)$ & $(-10.63)$ \\
\hline \multirow[t]{2}{*}{ Finex } & & & & & $0.056^{*}$ & 0.083 & $0.213 * * *$ & 0.012 \\
\hline & & & & & $(-1.73)$ & $(-1.15)$ & $(-3.33)$ & $(-0.21)$ \\
\hline \multirow[t]{2}{*}{ Finex $*$ Pre } & & & & & $2.062 * * *$ & $2.706^{* * *}$ & $1.562 * * *$ & $2.192 * * *$ \\
\hline & & & & & $(-7.51)$ & $(-4.65)$ & $(-2.93)$ & $(-5.57)$ \\
\hline \multirow{2}{*}{\multicolumn{2}{|c|}{ Finex*Down*Pre }} & & & & $-0.774^{*}$ & $-1.897 * *$ & 0.005 & -0.586 \\
\hline & & & & & $(-1.91)$ & $(-2.19)$ & $(-0.01)$ & $(-1.00)$ \\
\hline \multirow[t]{2}{*}{ Constant } & $11.185 * * *$ & $11.876^{* * *}$ & $10.969 * * *$ & $11.106 * * *$ & $11.195 * * *$ & $11.814 * * *$ & $10.996^{* * *}$ & $11.127 * * *$ \\
\hline & $(-135.45)$ & $(-69.70)$ & $(-78.54)$ & $(-93.58)$ & $(-135.38)$ & $(-68.96)$ & $(-79.75)$ & $(-93.31)$ \\
\hline industry & Yes & Yes & Yes & Yes & Yes & Yes & Yes & Yes \\
\hline year & Yes & Yes & Yes & Yes & Yes & Yes & Yes & Yes \\
\hline \multicolumn{2}{|c|}{ Observations 15,225} & 2,172 & 4,021 & 9,032 & 15,225 & 2,172 & 4,021 & 9,032 \\
\hline adj. $R^{2}$ & 0.263 & 0.385 & 0.292 & 0.260 & 0.269 & 0.397 & 0.300 & 0.266 \\
\hline $\mathrm{F}$ & 144.50 & 43.28 & 56.23 & 86.47 & 138.50 & 41.60 & 6.33 & 80.39 \\
\hline
\end{tabular}


Notes: Standard deviation in brackets. *, **,*** significant at $0.10,0.05$ and 0.01 levels.

The results showed the restraint effect of financial excesses on compensation stickiness, which confirmed the Hypothesis 2. According to model 2, in the group test based on the nature of the actual controller, the stickiness values of the executive compensation of local government and private enterprise were 1.00 and 1.40 respectively, both of which were significantly lower than the stickiness values of 1.98 and 2.66 before the financial excesses was added. It is worth noting that the executive compensation stickiness value of the central state-owned enterprises rose to 8.00 , which is a significant improvement over the stickiness value before adding the financial excesses of 1.44. The financial excesses significantly promoted the impact of the compensation stickiness on the central stateowned enterprises, thereby verifying Hypothesis 3 .

\subsection{Robustness Test}

In this paper, the average compensation of the top three directors ' compensation is used instead of the top three executives' compensation to test the robustness of Model 1 and Model 2. The stickiness value $\beta_{1} /\left(\beta_{1}+\beta_{3}\right)$ is 1.93. The stickiness values of central state-owned enterprises, local state-owned enterprises and private enterprises are 1.61, 1.84 and 1.73 respectively, which are basically consistent with the results of empirical research using executive compensation. When using the model 2 to test the adjustment of financial excesses, the stickiness value of 1.51 is significantly lower than the stickiness value of 1.93 of the full sample in the model 1, thus confirming Hypothesis 2. The stickiness values of central state-owned enterprises, local state-owned enterprises and private enterprises are 9.25, 1.00 and 1.31 respectively, consistent with Hypothesis 3. This paper also uses Roa to measure company performance, which is basically consistent with the above results, and due to space limitations we will not continue to discuss here.

\section{CONCLUSION}

This research empirically tests the impact of financial affluence and property rights on the executive compensation stickiness. This study finds that financial excesses have a significant regulating effect on executive compensation stickiness, and the degree of stickiness regulation for enterprises with different property rights is quite different. Financial excesses inhibit executive compensation stickiness in local-state-owned enterprises and non-state-owned enterprises, but have a positive effect when it happens in central-state-owned enterprise. In the future, we will explore the differences in the effects of other capital structure characteristics on executive compensation stickiness.

\section{References}

1. Gaver J J, Gaver K M. 1998. The relation between nonrecurring accounting transactions and CEO cash compensation[J]. Accounting Review,73(2):235-253.
2. Gan Shengdao, Chen Ran, Hu Dan Semba. 2020. Financial Excesses: Concept Creation and Research Topics[J]. Friends of Accounting, (01): 10-13.

3. Jackson S B, Lopez T J, Reitenga A L. 2008. Accounting fundamentals and CEO bonus compensation[J]. Journal of Accounting and Public Policy, 27(5): 374-393.

4. Fang Junxiong. 2009. Is Top Management Compensation of Chinese Public Companies Sticky? [J]. Economic Research Journal, 44(03): 110-124.

5. Bu Danlu, Cai Chun, Ye Jianming. 2010. Research on the Fairness of Executive Compensation-A Quantitative Approach Based on Comprehensive Theoretical Analysis[J]. Accounting Research, (05): 39-46.

6. Zhao Jianmei, Ren Xuewei. 2014. CEO Compensation Structure and Stickiness of Stateowned Listed Companies in China[J]. On Economic Problems, (10): 57-61.

7. Mao Hongtao, Zhou Dayong, Wang Xin. 2012. Research on the Governance Effect of the Compensation Committee on the Effectiveness of Executive Compensation Incentives - An Empirical Study Based on A-share Listed Companies from 2002 to $2010[\mathrm{~J}]$. Review of Investment Studies, 31(09): 20-41.

8. Zhang Aimin, Sang Yinyin, Lu Yunshi. 2016. Political Connection, Nature of Property Right and Executive Compensation Stickiness: Evidence from China's A Share Listed Companies [J]. Journal of Accounting and Economics, 30(02): 54-66.

9. Zhu Xingwen, Cai Jifu, Xie Shengwen. 2008. Study on Corporate Governance, Earnings Quality, and Top Executive Compensations[J]. Nankai Business Review, (02): 28-33.

10. Gao Wenliang, Luo Hong, Cheng Peixian.2011. Managerial Power and Executive Compensation Stickiness[J]. Economic Survey, (06): 82-86.

11. Dai Bin, Peng Cheng, Hao Ying. 2011. State-owned Corporate Executive Control, Audit Supervision and Accounting Information Transparency[J]. Journal of Finance and Economics, 37(11): 113-123.

12. Luo Hong, Wan Lingyu, Liu Baohua. 2014. On Compensation Contract Manipulation of SOE Chief Executives: From the Perspective of the Choice of Performance Evaluation Indexes[J]. Journal of Finance and Economics, 40(04): 79-89.

13. Wang Junqiu, Zhang Qifeng. 2009. Information Transparency and Executive Compensation Contract: Evidence from Chinese Security Market[J]. Nankai Business Review, 12(05): 94-100.

14. Wang Haiping. 2010. Research on Sensitivity of Executive Compensation of Listed Companies in Zhejiang[J]. Statistical Science and Practice, (06): 31-33.

15. Xu Yue, Liu Yunguo, Cai Guilong.2018.Motivation Innovation through Sticky Compensation 
Contracts-Evidence from China $[\mathrm{J}]$.Accounting Research,(07):43-49.

16. Zhang Huarong, Li Bo.2018. Does Managerial Power Increase the Stickiness of Executive Compensation in Listed Companies? [J].Research on Financial and Economic Issues,(06):66-72

17. Zhang Hannan, Sun Shimin, Ma Zhiying.2019. A Study on the Formation Mechanism of Senior Executive Compensation Stickiness: From the Perspective[J]. Accounting Research, (04): 65-73.

18. Quan Xiaofeng, Wu Shinong, Wen Fang.2010. Managerial Power, Private Income and Compensation Rigging[J]. Economic Research Journal, 45(11): 73-87.
19. Lei Yu, Guo Jianhua.2017. Rule Fairness and Employee Efficiency--based on the Stickiness Gap between Executives and Employees, Management World, (01): 99-111.

20. Lu Rui, Liu Jianhua, Xu Ning.2011. Internal Control, Property Right and Executive Pay-performance Sensitivity. Accounting Research, (10): 42-48.

21. Song Zengji, Zhang Guojie, Guo Guixi.2013. Political Identity of Top Management And Firm Performance: A View from Political Incentives of Individual-controlled Listed Firms $[\mathrm{J}]$. Journal of Audit \& Economics, 28(01): 95-103. 